\title{
Planting Density and Time of Safflower Relay Intercropping in Tef (Eragrostis Tef) at Sebatamit Kebele in Bahir Dar Zuria District, Amhara Region
}

\author{
Hosaena Tilahun \\ School of Agriculture, Deberemarkos University, Po box 18, Deberemarkos university \\ Getahew Alemayehu (phD) \\ School of Agriculture, Bahir Dar University, Bahir Dar, Ethiopia, P.O.Box 79
}

\begin{abstract}
On-farm factorial experiment was conducted during the main cropping season of 2015/16 in Bahir Dar Zuria District, at Sebatamit village to study the effect of planting density and time of safflower relay intercropping in tef on growth and yields of components crops. Factorial combinations of three time of safflower relay intercropping (42, 57 and 72 days after tef sowing DATS), two inter-row spacing (40 and $60 \mathrm{~cm})$ and two intrarow spacing (20 and $30 \mathrm{~cm}$ ), and two sole cropping of tef and safflower were laid out in randomized complete block design (RCBD) at three replications. "Kuncho" Tef and "Quihar" safflower cultivars were used as experimental planting materials. The ANOVA results showed that, except grain yield, all growth and yield parameters of tef were not significantly affected by main and interaction effects of planting density and time of safflower relay intercropping in tef. The main and interaction effects of time of relay cropping, inter- and intrarow spacing of safflower were significant on most growth and yield components of safflower crop. The highest grain yield of safflower was recorded in the treatment combination of relay intercropping after 42 days of tef sowing and $60 \mathrm{~cm}$ by $20 \mathrm{~cm}$ inter- and intra-row spacing of safflower $(1307.19 \mathrm{k} . \mathrm{g} / \mathrm{ha})$. Indeed, relay intercropping of safflower after 57 days of tef sowing had also similar effect on safflower grain yield as that of 42 days. The lowest grain yield of safflower was recorded in the treatment combination of relay cropping after 72 days of tef sowing and $60 \mathrm{~cm}$ by $20 \mathrm{~cm}$ inter- and intra-row spacing of safflower $(163.39 \mathrm{k} . \mathrm{g} / \mathrm{ha})$. The highest land equivalent ration-LER (1.79) and monetary advantage index-MAI (34563.28 birr ha-1) were obtained from the treatment combination of 42 DATS and $60 \mathrm{~cm}$ by $20 \mathrm{~cm}$ inter- and intra-row spacing of safflower. The result clearly showed that, with relay intercropping of safflower in tef, it is possible to produce additional yield of safflower without significant reduction in tef yield. As a result of this, safflower relay intercropping after 42 days of tef sowing, after three tef row with $20 \mathrm{~cm}$ intra row spacing can be recommended as an efficient relay intercropping system to be used by the farmers around the study area.
\end{abstract}

Keywords: Tef; safflower; relay intercropping; inter- and intra-row spacing; growth and yield components DOI: $10.7176 / \mathrm{JBAH} / 9-7-04$

Publication date: April $30^{\text {th }} 2019$

\section{Chapter 1. INTRODUCTION \\ 1.1. Background and Rationale}

Intercropping is an important practice for the development of sustainable food production systems, particularly in cropping system with limited external inputs (Getachew Amare et al., 2006). This is due to some of the potential benefits of intercropping systems such as high productivity and profitability. Crop intercropping is commonly practiced because of various advantages such as greater yield stability, greater land-use efficiency, increased competitive ability toward weeds, improvement of soil fertility due to the addition of $\mathrm{N}$ by fixation, and some favorable exudates from legume species. Lithourgidis et al., (2006), demonstrated that yield productivity under intercropping was higher than that of sole cropping systems. This is because of resources such as water, light and nutrients can be utilized more efficiently than in the respective sole cropping systems. The essential features of intercropping systems are intensification in space and time, competition between and among the system components for light, water, and nutrients, and the proper management of these interactions (Oseni et al., 2010). Recently, indeed, the hope of increasing tef productivity in the country is sparked by growing it in rows with reduced seeding rates and seedling transplanting. Beyond increasing its productivity per se, the efforts must also be extended to increase the productivity of tef fields using efficient cropping system such as intercropping and relay intercropping with other crops without negatively affecting its productivity significantly.

Mixed cropping has been practiced in many parts of the world as a way to maximize land productivity in a specific area in a growing season. Mixed cropping is often superior to sole cropping in terms of insurance against risk, efficient use of resources and higher net returns. Most successful mixtures have been of legumes with nonlegumes. There are also few reports showing success in the intercropping of non-legume with non-legume crops. Putnam and Allan (1992) reported a yield advantage from mixed planting of sunflower and mustard over their 
sole crops. The yield benefits in such mixtures must have been due to complementary rather than competitive use of resources.

In Ethiopia some farmers grow tef with the mixture of safflower in different place. But, such practice was not yet scientifically well studied. On the other hand, safflower (Carthamus tinctorius L.) nowadays has gained the reputation of being an edible oil of superior quality containing high levels of unsaturated fatty acids, such as oleic and linoleic acids, associated with the reduction of cholesterol level in the human blood (Chaturvedi et al., 2001). Although safflower grows on a small scale level in some parts of Tigray, Amhara and Oromia Regional States at altitudes ranging from 1000 to 2400 m.a.s.l. (Tadesse 2004), its low productivity per unit area doesn't encourage farmers to expand it at wider scale. In areas where arable land becomes scarce, growing of low productive crops like safflower as sole will be dwindled much ever before; unless it can be intercropped with other productive crops.

Hence, growing of safflower (Carthamus tinctorius L.) in tef (Eragrostis Tef) fields as intercrop or relay intercrop without significantly affecting tef productivity would be a big advantage to tef growing farmers in particular and to the country in general, while it increases the productivity of tef fields per unit area as well as it creates a great opportunity to expand and increase the production of safflower. Prior to recommend and popularize intercropping or relay intercropping of safflower with tef, however, optimum plant density as well as time of intercropping or relay intercropping of safflower in tef fields should be well known.

\subsection{Statement of the problem}

As Ethiopian people and the population becomes increase up to date, the present production system and land use efficiency cannot satisfy the consumers demand since Ethiopian farmers use traditional and mono-cropping system which is not supported by different cropping systems due to less understanding of the effectiveness of intercropping system rather than sole cropping. Especially tef relay intercropping with different crops was not practiced in the experiment site unless mostly use sole cropping system. The proposed study was therefore targeted at the following main and specific objectives.

\subsection{Objectives}

\subsubsection{General objective}

The main objective of this experiment was to study the potential of increasing the productivity of tef fields per unit area through relay intercropping of safflower

\subsubsection{Specific objectives}

- To determine the appropriate plant densities and time of safflower relay intercropping in tef for better growth and yield components of component crops in Bahir Dar Zuria District

- To assess the economic benefits of relay intercropping of safflower with tef in the study area

\section{Chapter 2. MATERIALS AND METHODS}

\subsection{Experimental Planting Materials}

The Tef variety known as "Quncho" (DZ-01-387) was used as the main test crop, while "Quihar" variety of safflower was used for relay intercropping in Tef fields. DAP and Urea were used as recommended rate.

\subsection{Experimental Treatments, Design and Procedures}

On properly plowed and prepared experimental plot, the combinations of 3 time of safflower relay intercropping (42, 57 and 72 days after Tef sowing), 2 inter-row spacing $(40 \mathrm{~cm}$ and $60 \mathrm{~cm})$ and 2 intra-row spacing $(20 \mathrm{~cm}$ and $30 \mathrm{~cm}$ ) of safflower plants, totally 12 treatment combinations, and two sole crops of Tef and safflower were laid out in randomized complete block design (RCBD) at three replications. In other words, the inter-row spacing of relayed safflower plant was laid between every two and three rows of tef which was planted at $20 \mathrm{~cm}$ inter-row spacing. The treatment combinations used for the presented study are presented below in Table 1 . The gross size of each experimental plot was $3 \mathrm{~m} \times 4 \mathrm{~m}(12 \mathrm{~m} 2)$ accommodating fourteen rows of tef and seven rows of safflower as a sole crop. Net plot area was varying upon crops. Net plot area for sole tef and safflower was $2.4 \mathrm{~m}$ x $3.4 \mathrm{~m}(8.16 \mathrm{~m} 2)$ and $2 \mathrm{~m}$ x $3.4 \mathrm{~m}(6.8 \mathrm{~m} 2)$, respectively. Indeed, the net plot area of relay intercropping was as that of sole tef, while safflower relay intercropping treatments were superimposed on Tef plots. Net plot area for safflower relay intercropping after two tef rows with $20 \mathrm{~cm}$ and $30 \mathrm{~cm}$ intra row spacing was $2.2 \times 3.4(7.48 \mathrm{~m} 2)$ and $2.2 \times 3.2(7.04 \mathrm{~m} 2)$, respectively and after three tef rows with $20 \mathrm{~cm}$ and $30 \mathrm{~cm}$ intra row spacing was $1.8 \mathrm{~cm}$ x $3.4 \mathrm{~cm}(6.12 \mathrm{~m} 2)$ and $1.8 \mathrm{~cm} \mathrm{x} 3.2 \mathrm{~cm}(5.76 \mathrm{~m} 2)$, respectively. Tef seeds were drilled in $20 \mathrm{~cm}$ apart rows in the last week of July at its recommended rate of $5 \mathrm{~kg} / \mathrm{ha}$. In relay intercropping, safflower seeds were sown as per the treatments, after two and three tef rows with its recommended inter and intra row spacing while in its sole cropping; its seeds were sown in rows at its recommended inter- and intra-row spacing of $40 \mathrm{~cm}$ and $20 \mathrm{~cm}$, respectively. In both relay and sole crops of safflower, two seeds per hill were planted and the weak plants were thinned after well established to allow a single plant per hill to grow further. 
Table 1: Treatment combinations used for the study

\begin{tabular}{l|l} 
Safflower plant density & Time of safflower relay intercropping after Tef sowing
\end{tabular}

\begin{tabular}{ll|lll} 
& & \multicolumn{3}{c}{ (Days) } \\
\hline Inter-row spacing & Intra-row spacing & 42 Days (D1) & 57 Days(D2) & 72 Days(D3) \\
\hline $40 \mathrm{~cm}(\mathrm{R} 1)$ & $20 \mathrm{~cm}(\mathrm{~A} 1)$ & D42R1A1 (T1) & D57R1A1 (T5) & D72R1A1 (T9) \\
& 30cm (A2) & D42R1A2 (T2) & D57R1A2 (T6) & D72R1A2 (T10) \\
\hline $60 \mathrm{~cm}(\mathrm{R} 2)$ & $20 \mathrm{~cm}(\mathrm{~A} 1)$ & D42R2A1 (T3) & D57R2A1 (T7) & D72R2A1 (T11) \\
& $30 \mathrm{~cm}(\mathrm{~A} 2)$ & D42R2A2 (T4) & D57R2A2 (T8) & D72R2A2 (T12)
\end{tabular}

Besides 12 treatment combinations (T1-T12), Tef and safflower sole crops were included as T13 \& T14, respectively, for comparison purposes.

Blocks were separated from each other by $1 \mathrm{~m}$ wide open spaces, while plots within a block were separated from each other by $0.5 \mathrm{~m}$ apart. All other agronomic practices were done as per their recommendations for tef and safflower in the study area.

\subsection{Data Collection}

\subsubsection{Soil Sampling and Analysis}

To characterize the soil of the experimental field with some important soil physico-chemical properties such as texture, $\mathrm{pH}, \mathrm{CEC}$, and contents of organic matter, total nitrogen and available phosphorous, a composite surface soil sample was taken from the experimental site before the application of the treatments. The composite soil sample of the experimental land was prepared as a mixture of several samples collected at $20 \mathrm{~cm}$ depth using a sampling technique of $\mathrm{W}$ - zigzag with the help of auger. The above mentioned physico-chemical soil properties of the composite sample was analyzed and determined in a soil laboratory using their respective standard methods and procedures, and the results are presented in Table 2. The soil of the study site are characterized as a clay texture with black to brown color, $\mathrm{pH}$ condition conductive for most crop growth, low organic carbon, low total nitrogen and medium available phosphorus.

Table 2: Some important physical and chemical properties of the surface soils $(0-20 \mathrm{~cm})$ of the study site

\begin{tabular}{|c|c|c|c|c|c|c|}
\hline $\begin{array}{c}\text { Depth } \\
\text { (cm) }\end{array}$ & $\begin{array}{c}\mathrm{pH} \\
\left(\mathrm{H}_{2} \mathrm{O}\right)\end{array}$ & $\mathrm{OC}(\%)$ & Total N (\%) & $\begin{array}{l}\text { Available P. (mg } \\
\left.\qquad \mathrm{kg}^{-1}\right)\end{array}$ & $\operatorname{CEC}\left(\mathrm{cmol}_{\mathrm{C}} \mathrm{kg}^{-1}\right)$ & Texture \\
\hline $0-20$ & 6.02 & 0.94 & 0.08 & 9.2 & 29.8 & Clay \\
\hline
\end{tabular}

2.3.2. Crops Growth and Yield Parameters

Phenological traits

The following phonological data for tef and safflower were recorded when the plants in each plot attained their respective growth stages:

Days to 50\% heading for Tef: The numbers of days elapsed from sowing up to the date when the tips of at least five panicles first emerge from the main shoot within net plot area. This was determined by visual observation of the heads on which the panicles emerged.

Days to $90 \%$ physiological maturity for Tef: The number of days elapsed from the date of sowing to the date when $90 \%$ of the crop was matured. This was reached when $90 \%$ of stand stems, leaves, and floral bracts in a plot changed to light yellow color were recorded and determined by visual observation.

Days to $50 \%$ seedling emergence for Safflower: The number of days elapsed from sowing up to the date when the plants in each plot grows above the ground and cover $50 \%$ of the area.

Days to $50 \%$ flowering for Safflower: The number of days elapsed from sowing up to the date when the plant forming $50 \%$ head in each plot.

Days to $90 \%$ physiological maturity for Safflower: The number of days elapsed from the date of sowing to the date when $90 \%$ of the crop was matured. This was reached when $90 \%$ of stand stems, leaves, and floral bracts in a plot changed to light yellow color were recorded and determined by visual observation.

Vegetative growth traits

Tef

The following growth parameters have been recorded when the plants attain their respective growth stages:

Average plant height: The height of the plant was recorded in meter from the ground level to the tip of the main Panicle at physiological maturity on the average of ten randomly selected plants within each net plot area using stick ruler.

Average Panicle length: length of the panicle in centimeter from the node where the first panicle branch starts to the tip of the main panicle at physiological maturity on an average of ten randomly selected plants within each net plot area was recorded using a plastic ruler.

Number of total tillers plant ${ }^{-1}$ : The number of effective and non-effective tillers per plant was counted from ten randomly selected plants before tillers appeared at physiological maturity within each net plot area. 
Number of effective tillers plant ${ }^{-1}$ : The number of effective tillers which was counted from ten randomly selected plants at physiological maturity within each net plot area.

\section{Safflower}

Stand count: The number of stand count which was counted from each plot at physiological maturity.

Average plant height: The height of the plant was recorded in meter from the ground level to the tip of flower at physiological maturity on the average of five randomly selected plants within each net plot area using stick ruler.

Number of primary branch plant $^{-1}$ : The number of primary branches was determined by counting the effective branch originating from main stem of five randomly selected plants at physiological maturity in each net plot area.

Number of secondary branch plant ${ }^{-1}$ : The number of secondary branches was determined by counting the branches which arises from primary branch. It was counted from all primary branches of five randomly selected plants at physiological maturity in net plot area.

Number of Tertiary branch plant ${ }^{-1}$ : The number of tertiary branches was determined by counting the branches which arises from secondary branch. It was counted from all secondary branches of five randomly selected plants at physiological maturity in net plot area.

\subsubsection{Grain yield and Related Traits}

Tef

Biomass yield ( $\mathrm{kg} \mathrm{ha}^{-1}$ ): At physiological maturity, the whole tef plants including leaves, stems, and panicles with seeds from the net plot area were harvested and sun dried. Then the biomass of harvested and dried tef plants with all their above ground parts was weighed just before threshing with spring balance and converted into hectare basis from the net plot area.

Grain yield ( $\left.\mathrm{kg} \mathrm{ha}^{-1}\right)$ : The total weight of the air-dried clean seeds harvested from each net plot area and converted into hectare basis. After sun drying of harvested tef plants and then threshed manually and cleaned with the help of wind, clean grains recovered from the net plot area were weighted with sensitive balance and converted into hectare basis.

Thousand seeds weight (g): After threshing was accomplished, 1000 seeds from each plot were counted and weighed separately using sensitive balance in gram.

Straw yield $\left(\mathrm{kg} \mathrm{ha}^{-1}\right)$ : straw yield was obtained when grain yield subtracted from total above ground biomass yield and harvest index was the ratio of grain yield to biological yield.

Harvest index (\%): was recorded as the ratio of grain yield to biomass yield and multiplied by 100 to put it as percentage.

\section{Safflower}

Average number of flower balls (heads): The number of flower balls per plant of 5 randomly selected plants in the net plot area was counted at the withering of $50 \%$ flowers.

Biomass weight $\left(\mathbf{k g ~ h a}^{-1}\right)$ : was taken as the weight of the stalk and the grain from each net plot area after harvesting and sun dried in field for two weeks. The dry biomass of all stalks and grain obtained from the net plot area was weighed with spring balance and converted into hectare basis.

Grain yield ( $\mathbf{k g ~ h a}^{-1}$ ): after two weeks sun drying of harvested safflower crops of each net plot area were threshed manually and clean grain yield was recovered through winnowing and weighed with sensitive balance. The grain yield obtained from net plot area was converted into hectare basis.

Thousand seeds weight: After threshing was accomplished, 100 seeds from each plot was counted and weighed separately using sensitive balance in gram and converted into 1000 seeds weight.

Harvest Index (\%): was recorded as ratio of economic yield (grain yield) and total plant mass (grain yield + shoot biomass).

\subsubsection{Total land productivity and gross return}

Land equivalent ratio (LER): is the most widely used relative index to evaluate the efficiency and productivity of intercropping (Willey, 1985). It is defined as the total land area required under sole cropping giving the yields obtained in the intercropping mixture (Mead and Willey, 1980). This is the amount of land planted in monoculture that would be needed to achieve the same yield produced by a mixture. Crop production is a function of crop duration (time) and land area but LER is based on land area only and does not take the duration of component crops in to consideration. Mathematically, when the value of LER is equal to 1 , there is no advantage to intercropping in comparison with sole cropping. And when the LER greater than 1, intercropping has an advantage over sole cropping. Thus, an LER less than 1 has no intercropping advantage and indicates that inter specific competition is stronger than inter specific facilitation in the intercropping system (Wahla et al., 2009).

$\mathrm{LER}=\mathrm{Xa} / \mathrm{Xs}+\mathrm{Ya} / \mathrm{Ys}$ Where, $\mathrm{Xa}$ and $\mathrm{Ya}$ are the individual crop yields in an intercropping

$\mathrm{Xs}$ and $\mathrm{Ys}$ are the yield of species $\mathrm{X}$ and $\mathrm{Y}$ as sole crops 


\section{Monetary Advantage Index (MAI)}

Economical advantage was assessed using monetary advantage index (MAI) to evaluate the economic advantage of intercropping as compared to sole cropping (Willey, 1979). The monetary advantage was determined by the existing local market price.

The most important part of recommending a cropping pattern is the cost: benefit ratio more specifically total profit, because farmers are mostly interested in the monetary value of return. The yield of all the crops in different intercropping systems and also in sole cropping system and their economic return in terms of monetary value were evaluated to find out whether grain yields are profitable or not. This was calculated with monetary advantage index (MAI). It is expressed as

$$
M A I=(P a b+P b a) \times \frac{(L E R-1)}{L E R}
$$

Where, $P a b=P a \times Y a b ; P b a=P b \times Y b a ; P a=$ Price of species 'a' and $\mathrm{Pb}=$ Price of species 'b'. The higher the index value, the more profitable is the cropping system.

\subsection{Data Analysis}

All collected data were subjected to analysis of variance (ANOVA) using JMP-5 (SAS 2002) software program. Significant differences between and /or treatment means were separated using least significance difference (LSD). Simple statistical mean and percentage was used to analyze the data obtained from the experiment.

\subsection{Economic Analysis}

To estimated economic parameters, Land equivalent ratio and monetary advantage index have a great value. Products were valued based on market price collected from local markets during January - February 2015 where Tef was 20.00 Ethiopian Birr (ETB) per kg of grain. Seed price of Safflower was $23.50 \mathrm{ETB} \mathrm{kg}^{-1}$.

\section{Chapter 3. RESULTS AND DISCUSSION}

\subsection{Crop phenology}

\subsubsection{Tef Phenology}

Days to Heading

The analysis of variance results showed that days to $50 \%$ heading of tef were not significantly affected $(\mathrm{P}>0.05)$ by plant density and time of safflower relay intercropping (Table 3). Similar to the present result, Yayeh Bitew and Fekremariam Asargew (2014) reported that all yield and yield components of rice were not significantly affected $(\mathrm{P}>0.05)$ by rice-chickpea relay intercropping at Fogera/Ethiopia. The authors further suggested that this might be due to early planting of rice in relay intercropping system takes advantage in peak resource demands for nutrients, water, and sunlight for all treatments.

Days to Physiological Maturity

Like that of days to $50 \%$ heading, days to $90 \%$ physiological maturity of tef was not also significantly affected $(\mathrm{P}>0.05)$ by main and interaction effects of time of relay intercropping, inter- and intra-row spacing of safflower (Tables 3, $4 \& 5$ ). This might be due to the delayed time of safflower sowing which was almost after heading of tef, and therefore safflower couldn't able to compete the growth of tef significantly. Similarly, the result of Melak Agajie (2014) showed that the interaction effect of inter- and intra-row spacing of chickpea did not show significant effect on days to physiological maturity. 
Table 3: Main effects of time of relay, inter- and intra-row spacing of safflower in Tef on pehnological traits of the component crops in 2015/16 in Bahir Dar District

\begin{tabular}{|c|c|c|c|c|c|}
\hline \multirow{2}{*}{$\begin{array}{l}\text { Treatments } \\
\text { Time of relay cropping (D) }\end{array}$} & \multicolumn{2}{|c|}{ Tef } & \multicolumn{3}{|c|}{ Safflower } \\
\hline & DH & DM & DE & DF & DM \\
\hline After 42 days (D1) & 52.75 & 103.25 & $12.00 \mathrm{c}$ & $107.00 \mathrm{c}$ & $142.83 c$ \\
\hline After 57 days (D2) & 52.67 & 103.50 & $14.00 \mathrm{~b}$ & $114.16 b$ & $149.33 b$ \\
\hline After 72 days (D3) & 52.67 & 103.50 & $15.41 \mathrm{a}$ & $125.33 \mathrm{a}$ & $159.16 \mathrm{a}$ \\
\hline Sig. difference & ns & ns & $* *$ & $* *$ & $* *$ \\
\hline $\mathbf{C V}$ & 1.31 & 1.41 & 8.45 & 0.81 & 2.58 \\
\hline $\mathbf{S E} \pm$ & 0.20 & 0.42 & 0.34 & 0.27 & 1.12 \\
\hline Inter-row spacing of safflower & & & & & \\
\hline $40 \mathrm{~cm}(\mathrm{R} 1)$ & 52.67 & 103.56 & 14.00 & 115.33 & 150.56 \\
\hline $60 \mathrm{~cm}(\mathrm{R} 2)$ & 52.72 & 103.28 & 13.61 & 115.66 & 150.33 \\
\hline Sig. difference & ns & ns & ns & ns & ns \\
\hline CV & 1.31 & 1.41 & 8.45 & 0.81 & 2.58 \\
\hline $\mathbf{S E} \pm$ & 0.16 & 0.34 & 0.27 & 0.22 & 0.92 \\
\hline Intra-row spacing of safflower & & & & & \\
\hline $20 \mathrm{~cm}(\mathrm{~A} 1)$ & 52.72 & 103.28 & 14.00 & 115.78 & 150.33 \\
\hline $30 \mathrm{~cm}(\mathrm{~A} 2)$ & 52.67 & 103.56 & 13.61 & 115.22 & 150.56 \\
\hline Sig. difference & ns & ns & ns & ns & ns \\
\hline $\mathbf{C V}$ & 1.31 & 1.41 & 8.45 & 0.81 & 2.58 \\
\hline $\mathbf{S E} \pm$ & 0.16 & 0.34 & 0.27 & 0.22 & 0.92 \\
\hline
\end{tabular}

$\mathrm{DH}=$ days to $50 \%$ heading; $\mathrm{DM}=$ days to $90 \%$ physiological maturity; $\mathrm{DE}=$ days to $50 \%$ emergency; $\mathrm{DF}=$ days to $50 \%$ flowering; $\mathrm{SC}=$ stand count per plot; $\mathrm{CV}=$ coefficient variation; $\mathrm{SE}=$ standard error; $* *$ highly significant difference at 0.01 level of significant; $n s=$ not significant at 0.05 level of significant; means followed with the same letter(s) are not significant difference at 0.05 level of significant.

\subsection{Vegetative Growth of Tef and Safflower \\ 3.2.1. Tef Vegetative Growth Parameters}

Plant Height

In the result of this experiment, plant height of tef was not significantly $(P>0.05)$ affected by both main and interaction effects of time of relay intercropping, inter-and intra-row spacing of safflower (Table 6 and 7). As the result of Tesfu Mengistu and Charles Yamoah (2010), Plant density and its interaction with sowing date had no significance $(\mathrm{P}>0.05)$ effect on plant height of carrot. There was no significant difference on plant height between sole tef crop and relay intercropping with safflower after three different relay times. Similarly, the study on rice-chickpea relay intercropping, plant height $(\mathrm{cm})$ of rice did not significantly affected $(\mathrm{P}>0.05)$ by the cropping system (Yayeh Bitew, 2014). The authors further suggested that this might be due to early planting of rice in relay intercropping system takes advantage in peak resource demands for nutrients, water, and sunlight for all treatments. In contrary, Tamiru Hirpa (2014) reported that there were significant differences in maize height due to varying intercropping time of the companion haricot bean crop. The tallest plant height $(140.70 \mathrm{~cm})$ and the shortest plant height $(137.70 \mathrm{~cm})$ almost have insignificant difference with each other. As Yayeh (2014) research result on field pea showed that inter-row spacing had no significant effect on all growth, yield and yield component of field pea varieties. Moreover, the result of Flesch, Roger Delmar (1994) showed that there is no significant differences were observed in wheat height among relay intercropping of wheat and soybean.

As indicated in Table 8, three-way interaction effect of time of relay intercropping, inter and intra row spacing was not significantly affect plant height. The highest plant height of tef $(140.70 \mathrm{~cm})$ was recorded in relay intercropping of safflower after 52 days and $40 \mathrm{~cm}$ inter row spacing of tef sowing, while the shortest plant height of tef $(137.70 \mathrm{~cm})$ was observed in the relay intercropping of safflower after 42 days, $60 \mathrm{~cm}$ intra and 30 $\mathrm{cm}$ inter row spacing of tef sowing.

Panicle Length

Panicle length is not significantly affected $(\mathrm{P}>0.05)$ by the main and interaction effect of time of relay intercropping, inter-and intra-row spacing (Table 6,7 and 8). The highest and the lowest panicle length $0.50 \mathrm{~cm}$ and $0.46 \mathrm{~cm}$ was recorded in relay intercropping of safflower at 42 days ATS, $60 \mathrm{~cm}$ inter and $30 \mathrm{~cm}$ intra row spacing and at 52 days ATS, $40 \mathrm{~cm}, 60 \mathrm{~cm}$ intra and $30 \mathrm{~cm}$ inter row spacing respectively. Thus, crops with high panicle length could have higher grain, straw and biomass yields (Okubay Giday, et.al. 2014). But in current result there was insignificant difference of straw yield and biomass yield due to the panicle length difference. Similarly there was no significant difference in tef panicle length in tef - sunflower mixed cropping system (Wondimu. Bayu. 2007). 
Total Number of Tillers Plant ${ }^{-1}$

Time of relay intercropping, inter-and intra- row spacing of safflower had not any significant effect $(\mathrm{P}>0.05)$ on total number of tillers which had almost similar with sole tef crop. The highest and the lowest number of tillers were recorded on both main and interaction effects (Table 6,7 and 8). Almost all tef crop relays with safflower have the same total number of tillers per plant. The maximum total number of tillers plant ${ }^{-1}(8.43)$ was recorded in safflower relay intercropping after 72 days, $60 \mathrm{~cm}$ intra-and $20 \mathrm{~cm}$ inter-row spacing of tef, while minimum total number of tiller plant ${ }^{-1}$ (6.70) was recorded in safflower relay intercropping after 72 days, $40 \mathrm{~cm}$ inter-and $20 \mathrm{~cm}$ intra-row spacing. The result is due to the delay time of relay intercropping of safflower which has not any influence on tef total number of tillers.

Number of Effective Tillers Plant ${ }^{-1}$

As the number of effective tillers plant ${ }^{-1}$ increases the yield hectare ${ }^{-1}$ also increases (Hamelmal, 2015). The number of effective tillers plant ${ }^{-1}$ is the most important of yield contributing component. As indicated in (Table 6 , 7 and 8 ) both the main and interaction effect of time of relay intercropping, inter and intra row spacing was not significant $(\mathrm{P}>0.05)$. The highest and the lowest number of effective tillers per plant $(6.60 \mathrm{~cm}, 5.36 \mathrm{~cm})$ was recorded in the relay intercropping of safflower at 42 days ATS, $60 \mathrm{~cm}$ inter and $30 \mathrm{~cm}$ intra row spacing and at 52 days ATS, $60 \mathrm{~cm}$ inter and $30 \mathrm{~cm}$ intra row spacing respectively which had almost similar number of effective tillers might had been recorded due to less competition of delayed safflower relay intercropping and different growth habit of crops.

Table 4: Main effects of time of relay, inter and intra- row spacing of safflower in Tef on vegetative growth parameters of the component crops in 2015/1016 in Bahir Dar District, Amhara Region

\begin{tabular}{|c|c|c|c|c|c|c|c|c|c|}
\hline \multirow{2}{*}{$\begin{array}{l}\text { Treatments } \\
\text { Time of relay cropping (D) }\end{array}$} & \multicolumn{4}{|c|}{ Tef } & \multicolumn{5}{|c|}{ Safflower } \\
\hline & PH & PL & TT & ET & SC & PH & PB & SB & TB \\
\hline After 42 days(D1) & 139.85 & 0.49 & 7.89 & 6.20 & $67880 a$ & $0.93 \mathrm{a}$ & $10.38 \mathrm{a}$ & $20.68 \mathrm{a}$ & $7.36 \mathrm{a}$ \\
\hline After 57 days(D2) & 139.47 & 0.48 & 7.23 & 5.81 & $65130 \mathrm{a}$ & $0.91 \mathrm{a}$ & $7.56 b$ & $13.91 b$ & $4.65 b$ \\
\hline After 72 days(D3) & 139.39 & 0.47 & 7.22 & 5.63 & $30864 b$ & $0.83 b$ & $3.83 \mathrm{c}$ & $5.03 \mathrm{c}$ & $0.00 \mathrm{c}$ \\
\hline Sig. difference & ns & ns & ns & ns & $* *$ & $* *$ & $* *$ & $* *$ & $* *$ \\
\hline $\mathbf{C V}$ & 1.44 & 4.53 & 14.86 & 14.13 & 28.34 & 2.85 & 10.59 & 20.90 & 19.96 \\
\hline $\mathrm{SE} \pm$ & 0.58 & 0.01 & 0.32 & 0.24 & 4474.80 & 0.01 & 0.22 & 0.80 & 0.58 \\
\hline \multicolumn{10}{|l|}{$\begin{array}{llll}\text { Inter row } & \text { spacing } & \text { of } \\
\text { Safflower } & \end{array}$} \\
\hline $40 \mathrm{~cm}(\mathrm{R} 1)$ & 139.98 & 0.48 & 7.60 & 5.98 & $62096 a$ & 0.89 & 7.50 & 13.82 & 4.24 \\
\hline $60 \mathrm{~cm}(\mathrm{R} 2)$ & 139.16 & 0.48 & 7.30 & 5.78 & $47153 b$ & 0.88 & 7.02 & 12.60 & 3.77 \\
\hline Sig. difference & ns & ns & ns & ns & $* *$ & ns & ns & ns & ns \\
\hline CV & 1.44 & 4.53 & 14.86 & 14.13 & 28.34 & 2.85 & 10.59 & 20.90 & 19.96 \\
\hline $\mathbf{S E} \pm$ & 0.48 & 0.01 & 0.26 & 0.20 & 3653.66 & 0.01 & 0.18 & 0.65 & 0.47 \\
\hline \multicolumn{10}{|l|}{$\begin{array}{l}\text { Intra row spacing of } \\
\text { Safflower }\end{array}$} \\
\hline $20 \mathrm{~cm}(\mathrm{~A} 1)$ & $139.66 \mathrm{a}$ & $0.48 \mathrm{a}$ & $7.55 \mathrm{a}$ & $5.93 \mathrm{a}$ & $53500 \mathrm{a}$ & $0.89 \mathrm{a}$ & $7.35 \mathrm{a}$ & $12.67 \mathrm{a}$ & $3.82 \mathrm{a}$ \\
\hline $30 \mathrm{~cm}(\mathrm{~A} 2)$ & $139.48 \mathrm{a}$ & $0.48 \mathrm{a}$ & $7.34 \mathrm{a}$ & $5.83 \mathrm{a}$ & $55748 \mathrm{a}$ & $0.88 \mathrm{a}$ & $7.17 \mathrm{a}$ & $13.74 \mathrm{a}$ & $4.18 \mathrm{a}$ \\
\hline Sig. difference & ns & ns & ns & ns & ns & ns & ns & ns & ns \\
\hline $\mathrm{CV}$ & 1.44 & 4.53 & 14.86 & 14.13 & 28.34 & 2.85 & 10.59 & 20.90 & 19.96 \\
\hline $\mathbf{S E} \pm$ & 0.48 & 0.01 & 0.26 & 0.20 & 3653.66 & 0.01 & 0.18 & 0.65 & 0.47 \\
\hline
\end{tabular}

$\mathrm{PH}=$ plant height; $\mathrm{PL}=$ panicle length; $\mathrm{TT}=$ total tiller; $\mathrm{ET}=$ effective tiller; $\mathrm{SC}=\mathrm{Stand}$ count; $\mathrm{PB}=\mathrm{Primary}$ branch; $\mathrm{SB}=$ Secondary branch; $\mathrm{TB}=$ Tertiary branch; $\mathrm{CV}=$ coefficient variation; $\mathrm{SE}=$ standard error; $* *$ highly significant difference at 0.001 level of significant; **significant difference at 0.01 level of significant; Ns=not significant at 0.05 level of significant; means followed with the same letter(s) are not significant difference at 0.05 level of significant

\subsection{Grain Yield and Related Traits of Tef and Safflower} 3.3.1. Tef Grain Yield and Related Traits

Biomass Weight

The main and interaction effect of time of relay intercropping, inter and intra row spacing was not significant $(\mathrm{P}>$ 0.05) on biomass weight. Similarly, the result of Ibrahim Yahuza (2012) showed that Wheat biomass yield significantly affected by wheat-bean intercropping system except when bean-sowing date was delayed by 37 days. The highest biomass weight of tef $(7657.18 \mathrm{~kg} / \mathrm{ha})$ was recorded in the three-way interaction of first time of relay intercropping (42 days ATS), inter $(60 \mathrm{~cm})$ and intra $(30 \mathrm{~cm})$ row spacing while the lowest biomass weight of tef $(7412.08 \mathrm{~kg} / \mathrm{ha})$ was recorded in the three-way interaction of both second and third time of relay intercropping $(57,72$ days ATS) with inter $(60,40 \mathrm{~cm})$ and intra $(30,20 \mathrm{~cm})$ row spacing respectively which is almost similar (Table 9, 10,11). This is due to the delay time of relay intercropping of safflower. 


\section{Thousand Grain Weight}

As the analysis of variance results showed that time of relay intercropping, inter and intra row spacing and their interaction had not any significant effect $(\mathrm{P}>0.05)$ on thousand grain weight of tef (Table 9, 10 and 11). Similar to this result, both the main and the interaction effects of inter- and intra-row spacing were not showing statistically significant change for 1000 seed weight of field pea (Yayeh. Bitew. et.al. 2014). The highest and lowest 1000 grain weights were recorded as 0.28 and 0.27 at all factors respectively. Moreover, inter-and intrarow spacing had not significant effect on 1000 grain weight and harvest index of faba bean. (Moussawi s.h. et al. 2010).

Grain Yield

Tef grain yield was not significantly affected $(\mathrm{P}>0.05)$ by both main and interaction effect of inter-and intra-row spacing in Tef-safflower relay intercropping but not time of relay intercropping and the interaction of time of relay intercropping and intra-row spacing. This may be due to the other factor which can affect the grain yield of tef like climatic condition, soil condition and seed arrangement. The highest grain yield was recorded during the three-way interaction of first time of relay intercropping (42 days ATS), second inter $(60 \mathrm{~cm})$ and intra-row (30 $\mathrm{cm})$ spacing $(2428.43 \mathrm{k.g} / \mathrm{ha})$ and followed by the interaction of first time of relay intercropping with second intra-row spacing $(2416.17 \mathrm{k} . \mathrm{g} / \mathrm{ha})$. The lowest grain yield which was recorded during the three-way interaction of second time of relay intercropping, inter-and intra-row spacing $(2314.05 \mathrm{k.g} / \mathrm{ha})$ (Table $9,10,11)$.

In contrary, there was significant difference in grain yield between the interaction of inter- and intra- row spacing. Average seed yield ranged from $989.1 \mathrm{~kg} \mathrm{ha}^{-1}(5 \mathrm{~cm})$ to $711.6 \mathrm{~kg} \mathrm{ha}^{-1}(30 \mathrm{~cm})$. Ö. Öztürk, O. Şaman, (2012) Found that wider row spacing's of sesame decreased the highest seed yield $\left(865.5 \mathrm{~kg} \mathrm{ha}^{-1}\right)$ was obtained from the narrow row spacing $(30 \mathrm{~cm})$ whereas the lowest seed yield $\left(767.3 \mathrm{~kg} \mathrm{ha}^{-1}\right)$ was determined from the widest row spacing $(70 \mathrm{~cm})$.

Straw Yield

Straw yield of tef was not significantly affected $(\mathrm{P}>0.05)$ by both the main and interaction effect of time of relay intercropping, intra-and inter-row spacing. Maximum straw yield $(5228.75 \mathrm{k} . \mathrm{g} / \mathrm{ha})$ was recorded in safflower relay intercropping at 42 days ATS, $60 \mathrm{~cm}$ inter-and $20 \mathrm{~cm}$ intra-row spacing while minimum straw yield $(4934.63 \mathrm{k} . \mathrm{g} / \mathrm{ha})$ was recorded in safflower relay intercropping at 42 days ATS, $60 \mathrm{~cm}$ inter-and $30 \mathrm{~cm}$ intra-row spacing which are almost similar with sole Tef straw yield $(5073.53 \mathrm{k} . \mathrm{g} / \mathrm{ha})($ Table $9,10,11)$.

Harvest Index

As the analysis of variance results showed that both main and interaction effect of time of relay intercropping, inter-and intra- row spacing -not significant effect $(\mathrm{P}>0.05)$ on harvest index of tef crop (Table 9, 10 and 11). Similarly bean-sowing date did not have significant effect on wheat harvest index $(\mathrm{P}>0.05)$ (Ibrahim Yahuza 2012).

Table 5: Main effects of time of relay, inter and intra- row spacing of safflower in Tef on grain yield and related traits of the component crops in 2015/1016 in Bahir Dar District, Amhara Regi

\begin{tabular}{|c|c|c|c|c|c|c|c|c|c|c|c|}
\hline \multirow{2}{*}{$\begin{array}{l}\text { Treatments } \\
\text { Time of relay } \\
\text { cropping (D) }\end{array}$} & \multicolumn{5}{|c|}{ Tef } & \multicolumn{6}{|c|}{ Safflower } \\
\hline & BM & $\mathbf{Y}$ & SY & TSW & HI & NH & BM & $\mathbf{Y}$ & SY & HSW & HI \\
\hline After 42 days(D1) & 7524.43 & $2408.01 \mathrm{a}$ & 5055.14 & 0.28 & 32.31 & $37.92 \mathrm{a}$ & $7504.3 \mathrm{a}$ & $1250.32 \mathrm{a}$ & $6227.71 \mathrm{a}$ & $4.02 \mathrm{a}$ & $16.97 \mathrm{a}$ \\
\hline After 57 days(D2) & 7473.36 & $2385.54 \mathrm{ab}$ & 5114.37 & 0.27 & 31.61 & $26.05 b$ & $7262.3 \mathrm{a}$ & $1251.17 \mathrm{a}$ & $6136.58 \mathrm{a}$ & $3.85 b$ & $17.07 \mathrm{a}$ \\
\hline After 72 days(D3) & 7463.15 & $2358.98 b$ & 5128.67 & 0.28 & 31.75 & $8.70 \mathrm{c}$ & $4549.2 b$ & $212.91 \mathrm{~b}$ & $4245.58 \mathrm{~b}$ & $1.46 \mathrm{c}$ & $4.86 \mathrm{~b}$ \\
\hline Sig. difference & ns & $*$ & ns & ns & ns & $* *$ & $* *$ & $* *$ & $* *$ & $* *$ & $* *$ \\
\hline CV & 3.99 & 1.99 & 6.12 & 6.59 & 4.81 & 19.08 & 5.19 & 7.88 & 2.29 & 4.57 & 9.57 \\
\hline $\mathrm{SE} \pm$ & 86.36 & 13.71 & 90.12 & 0.01 & 0.44 & 1.33 & 96.65 & 20.60 & 36.71 & 0.04 & 0.36 \\
\hline \multicolumn{12}{|l|}{$\begin{array}{l}\text { Inter row spacing } \\
\text { of Safflower }\end{array}$} \\
\hline $40 \mathrm{~cm}(\mathrm{R} 1)$ & 7486.98 & 2379.41 & 5100.8 & 0.28 & 31.82 & 25.07 & $5874.6 b$ & 902.40 & $4903.81 \mathrm{a}$ & 3.12 & $14.21 \mathrm{a}$ \\
\hline $60 \mathrm{~cm}(\mathrm{R} 2)$ & 7486.98 & 2388.94 & 5098.0 & 0.27 & 31.96 & 23.37 & $7002.6 \mathrm{a}$ & 907.19 & $6169.43 b$ & 3.11 & $11.73 b$ \\
\hline Sig. difference & ns & ns & ns & ns & ns & ns & $* *$ & ns & $* *$ & ns & $* *$ \\
\hline $\mathrm{CV}$ & 3.99 & 1.99 & 6.12 & 6.59 & 4.81 & 19.08 & 5.19 & 7.88 & 2.29 & 4.57 & 9.57 \\
\hline $\mathrm{SE} \pm$ & 70.51 & 11.19 & 73.58 & 0.01 & 0.36 & 1.09 & 78.91 & 16.82 & 29.97 & 0.03 & 0.29 \\
\hline \multicolumn{12}{|l|}{$\begin{array}{l}\text { Intra row spacing } \\
\text { of Safflower }\end{array}$} \\
\hline $20 \mathrm{~cm}(\mathrm{~A} 1)$ & 7555.06 & 2387.58 & 5031.31 & 0.27 & 32.24 & 23.41 & $6257.5 b$ & 914.37 & $5333.56 \mathrm{a}$ & 3.08 & $13.49 \mathrm{a}$ \\
\hline $30 \mathrm{~cm}(\mathrm{~A} 2)$ & 7418.90 & 2380.77 & 5167.48 & 0.28 & 31.54 & 25.04 & $6619.7 \mathrm{a}$ & 895.23 & $5739.68 \mathrm{~b}$ & 3.14 & $12.45 \mathrm{~b}$ \\
\hline Sig. difference & ns & ns & ns & ns & ns & ns & $* *$ & ns & $* *$ & ns & $* *$ \\
\hline $\mathrm{CV}$ & 3.99 & 1.99 & 6.12 & 6.59 & 4.81 & 19.08 & 5.19 & 7.88 & 2.29 & 4.57 & 9.57 \\
\hline $\mathrm{SE} \pm$ & 70.51 & 11.19 & 73.58 & 0.01 & 0.36 & 1.09 & 78.91 & 16.82 & 29.97 & 0.03 & 0.29 \\
\hline
\end{tabular}

$\mathrm{BM}=$ biomass weight; $\mathrm{Y}=$ grain yield; $\mathrm{SY}=$ straw yield; $\mathrm{TSW}=$ thousand seed weight; $\mathrm{HI}=$ harvest index; $\mathrm{NH}=$ number of head per plant; HSW= hundred seed weight; $\mathrm{CV}=$ coefficient variation; $\mathrm{SE}=$ standard error; $* *$ highly significant at 0.001 level of significant; **significant at 0.01 level of significant; *significant at 0.01 level of significant; ns=not significant at 0.05 level of significant; means followed with the same letter(s) are not significant difference at 0.05 level of significant 


\subsection{Productivity of Relay cropping}

One way to reduce competition for limited water and mineral nutrients is to plant crops at different times of the growing season in a relay-intercropping system (Andrews and Kassam, 1976). Relay intercropping is a system that can play an important role in increasing and diversifying grain production in areas where the growing season is too short to permit the cultivation of two crops in sequence. Land equivalent ratio and monetary advantage index ha ${ }^{-1}$ could be better indicators of relative advantages of different intercropping practices.

\subsubsection{Land Equivalent Ratio (LER)}

All relay intercropping systems resulted in yield advantages and all the components were compatible with one another. LER value of more than one indicates yield advantage than less value without any advantage. Among crop mixtures land equivalent ratio (LER) is used for estimating advantages or disadvantage of crop mixture over sole cropping systems (Willey, 1985). As the analysis of variance results showed that the total LER of tef and safflower is greater than 1. LER of safflower relay intercropping with tef were statistically highly significantly affected $(\mathrm{P}<0.001)$ by third time of relay intercropping. The highest LER $(1.79)$ was obtained by relay intercropping of safflower after 42 days of tef sowing, after three Tef row and $20 \mathrm{~cm}$ intra-row spacing. The lowest LER (1.09) was obtained by relay intercropping of safflower after 72 days of tef sowing, after three tef rows and $30 \mathrm{~cm}$ intra-row spacing (Table 14). Similarly the result of Walelign Worku (2004) showed that the LER values of maize-tef relay intercropping were greater than one for all treatments, which shows that the cropping system was efficient compared to sole cropping and Gholamreza R. (2011), LRE value of potatosafflower relay intercropping for all the treatments was above one; that is, in all the treatments the mixed cropping is preferable to the pure one. Moreover, Mead and Willey, (1980) reported that total LER values were higher in all the intercrops than one indicating the advantage of intercropping over sole stands in regard to use of environmental sources for plant growth and this similar case has also been reported where pea was intercropped with barley (Li et al., 1999).

Table 6: Main effects of time of relay, inter and intra- row spacing on land equivalent ratio and monetary advantage index of Tef and safflower in 2015/16 in Bahir Dar District

\begin{tabular}{|c|c|c|c|c|c|c|}
\hline \multirow[t]{2}{*}{ Treatments } & \multicolumn{2}{|l|}{ Grain yield } & \multirow[t]{2}{*}{$\begin{array}{l}\text { LER } \\
\end{array}$} & \multicolumn{2}{|c|}{ Yield price } & \multirow[b]{2}{*}{$\begin{array}{l}\text { MAI } \\
(\mathrm{Birr} / \mathrm{ha})\end{array}$} \\
\hline & $\begin{array}{l}\text { Tef } \\
(\mathrm{k} . \mathrm{g} / \mathrm{ha})\end{array}$ & $\begin{array}{l}\text { Safflower } \\
\text { (k.g/ha) }\end{array}$ & & $\begin{array}{l}\text { Tef } \\
\text { (Birr/ha) }\end{array}$ & $\begin{array}{l}\text { Safflower } \\
\text { (Birr/ha) }\end{array}$ & \\
\hline $\begin{array}{l}\text { Time of relay cropping } \\
\text { After } 42 \text { days (D1) } \\
\text { After } 57 \text { days (D2) } \\
\text { After } 72 \text { days (D3) }\end{array}$ & $\begin{array}{l}2408.00 \mathrm{a} \\
2358.98 \mathrm{ab} \\
2385.54 \mathrm{~b}\end{array}$ & $\begin{array}{l}1250.32 \mathrm{a} \\
1251.17 \mathrm{a} \\
212.91 \mathrm{~b} \\
\end{array}$ & $\begin{array}{l}1.76 \mathrm{a} \\
1.74 \mathrm{a} \\
1.11 \mathrm{~b}\end{array}$ & $\begin{array}{l}47363.5 \\
47751.6 \\
47935.4 \\
\end{array}$ & $\begin{array}{l}29382.6 \mathrm{a} \\
29402.6 \mathrm{a} \\
5003.4 \mathrm{~b} \\
\end{array}$ & $\begin{array}{l}33216.1 \mathrm{a} \\
32901.0 \mathrm{a} \\
5302.5 \mathrm{~b}\end{array}$ \\
\hline $\begin{array}{l}\text { Sig. difference } \\
\text { CV } \\
\text { SE } \pm\end{array}$ & $\begin{array}{l}* \\
1.99 \\
14.73 \\
\end{array}$ & $\begin{array}{l}* * \\
7.70 \\
\mathbf{2 0 . 6 0} \\
\end{array}$ & $\begin{array}{l}* * \\
2.84 \\
0.01\end{array}$ & $\begin{array}{l}\text { ns } \\
2.28 \\
332.28\end{array}$ & $\begin{array}{l}* * \\
7.70 \\
\mathbf{4 8 4 . 0 1} \\
\end{array}$ & $\begin{array}{l}* * \\
8.47 \\
637.89 \\
\end{array}$ \\
\hline $\begin{array}{r}\text { Inter row spacing } \\
40 \mathrm{~cm}(\mathrm{R} 1) \\
60 \mathrm{~cm}(\mathrm{R} 2) \\
\end{array}$ & $\begin{array}{l}2379.41 \\
2388.94 \\
\end{array}$ & $\begin{array}{l}902.40 \\
907.19\end{array}$ & $\begin{array}{l}1.53 \\
1.54 \\
\end{array}$ & $\begin{array}{l}47765.2 \\
47601.8 \\
\end{array}$ & $\begin{array}{l}21206.5 \\
21319.2 \\
\end{array}$ & $\begin{array}{l}23649.4 \\
23963.7\end{array}$ \\
\hline $\begin{array}{l}\text { Sig. difference } \\
\mathrm{CV} \\
\mathrm{SE} \pm \\
\end{array}$ & $\begin{array}{l}\text { ns } \\
1.99 \\
12.03 \\
\end{array}$ & $\begin{array}{l}\mathrm{ns} \\
7.70 \\
16.82 \\
\end{array}$ & $\begin{array}{l}\text { ns } \\
2.84 \\
0.01 \\
\end{array}$ & $\begin{array}{l}\text { ns } \\
2.28 \\
271.31 \\
\end{array}$ & $\begin{array}{l}\text { ns } \\
7.70 \\
395.19 \\
\end{array}$ & $\begin{array}{l}\text { ns } \\
8.47 \\
520.84 \\
\end{array}$ \\
\hline $\begin{array}{r}\text { Intra row spacing } \\
20 \mathrm{~cm}(\mathrm{~A} 1) \\
30 \mathrm{~cm}(\mathrm{~A} 2)\end{array}$ & $\begin{array}{l}2387.58 \\
2380.77\end{array}$ & $\begin{array}{l}914.37 \\
895.23\end{array}$ & $\begin{array}{l}1.54 \\
1.53\end{array}$ & $\begin{array}{l}47710.7 \\
47656.3\end{array}$ & $\begin{array}{l}21487.7 \\
21038.0\end{array}$ & $\begin{array}{l}24053.4 \\
23559.7\end{array}$ \\
\hline $\begin{array}{l}\text { Sig. difference } \\
\text { CV \% } \\
\text { SE } \pm \\
\end{array}$ & $\begin{array}{l}\text { ns } \\
1.99 \\
12.03 \\
\end{array}$ & $\begin{array}{l}\text { ns } \\
7.70 \\
16.82 \\
\end{array}$ & $\begin{array}{l}\text { ns } \\
2.84 \\
0.01 \\
\end{array}$ & $\begin{array}{l}\text { ns } \\
2.28 \\
271.31 \\
\end{array}$ & $\begin{array}{l}\text { ns } \\
7.70 \\
395.19 \\
\end{array}$ & $\begin{array}{l}\text { ns } \\
8.47 \\
520.84 \\
\end{array}$ \\
\hline
\end{tabular}

$\mathrm{LER}=$ land equivalent ratio; $\mathrm{MAI}=$ monetary advantage index; $\mathrm{CV}=$ coefficient of variation; $\mathrm{SE}=$ standard error; **highly significant at 0.001 level of level of significant; *significant at 0.05 level of level of significant; $n s=$ not significant at 0.05 level of level of significant; means followed with the same letter(s) are not significant at 0.05 level of level of significant

\subsubsection{Monetary Advantage Index}

As the analysis of variance results showed that monetary advantage index was highly significantly $(\mathrm{P}<0.001)$ affected by the main effect of third time of relay cropping (72 days ATS) but not the first and second time of relay cropping $(42,57$ days ATS) respectively and inter-and intra-row spacing. The two-way interaction effect of third time of relay cropping with inter-and intra-row spacing affect MAI at $\mathrm{P}<0.05$ but the interaction of interand intra-row spacing didn't affect MAI (Table 13 and 14). The highest MAI (34563.28birr ha ${ }^{-1}$ ) was recorded in safflower relay intercropping after 42 days of Tef sowing, after three Tef rows and $20 \mathrm{~cm}$ intra-row spacing while the lowest MAI (4453.14birr ha $\left.{ }^{-1}\right)$ was recorded in safflower relay intercropping after 72 days of tef 
sowing, after three tef row and $20 \mathrm{~cm}$ intra-row spacing. This indicates that the maximum yield was recorded at early time of relay cropping of safflower.

\section{Chapter 4. CONCLUSION AND RECOMMENDATIONS}

\subsection{Conclusion}

The outcome of this experiment concludes that relay intercropping of safflower with tef in different time of relay intercropping, inter- and intra- row spacing showed influence on yield and yield components of safflower crop but not on tef yield components except grain yield as compared with sole crop of tef because the time of relay intercropping was delayed by minimum of 42 days to active growth of tef crop and it becomes less competitive with different nutrients. The first and second time of relay intercropping of safflower on tef- safflower relay cropping system recorded the highest grain yield of safflower which is the best time of relay intercropping after 42 and 57 days of tef sowing. But the last time of relay intercropping had a great influence on grain yield of safflower which recorded the lowest grain of safflower due to inappropriate moisture content and shading effect of tef.

\subsection{Recommendations}

This experiment was not a common practice in the experiment site. The dominant traditional practice was sowing of local variety safflower with tef in broadcast method and it's also not common by most farmers and this day's it is almost rare practice. Even it was not profitable during their growing experience. However this research used one variety of tef and safflower. It has shown a better result in relation to that of their experience. So to realize this result it is recommended to repeat this research with different variety of tef and safflower at different soil types and across location.

\section{Reference}

Abdulhabip .ZEL, Tuncay Demurbulek, M. Atilla G.R, Osman .Opur (2003). Effects of Different Sowing Date and Intrarow Spacing on Yield and Some Agronomic Traits of Safflower (Carthamus tinctorius L.) Under Harran PlainÕs Arid Conditions

Adamu Molla and Kemelew Muhie (2010). Tef (Eragrostis tef) based cropping systems in the hot to warm moist valleys of North Shewa, Ethiopia

Adipala, E., Ocaya, C.P. and Osiru, D.S.O. (2002). Effect of time of planting cowpea (Vignaunguiculata (L.) walp.) Relative to maize (Zea mays 1.) on growth and yield of cowpea.TROPICULTURA20 (2): 49-57.

Ahmad M, Khan MJ and Muhammad D. (2013). Response of maize to different phosphorus levels under calcareous soil conditions. Sarhad J. Agric., 29(1): 43-48.

Al-Masri MR, (1998). Yield and nutritive value of vetch (Vicia sativa)- barley (Hordeumvulgare) forage under different harvesting regimens. Tropical Grasslands. 32: 201-206.

Andrew, D.J. and A.H. Kassam. (1976). The importance of multiple cropping in increasing world food supplies, p. 1-11. In: R.I. Papendick, P.A. Sanchez, and G.B. Triplett (eds.). Multiple cropping. Amer. Soc. Agron., Madison, Wis. Spec. Publ. 27.

Arif M, Ali A, Umair M, Munsif F, Ali K, Inamullah M, Saleem and Ayub G. (2012). Effect of biochar, FYM and mineral nitrogen alone and in combination on yield and yield components of maize. Sarhad J. Agric., 28(2): 191-195.

Atri A., Javanshir A., Mogaddam M. (1999). Evaluation of competition in corn/bean intercropping using convert model yield. Journal of Agriculture Science 17(4) 97-103 (In Persian with English abstract)

Awal, M.A., H. Koshi, and T. Ikeda (2006). Radiation interception and use by maize/peanut intercrop canopy. Agric. For. Meteorol. 139: 74-83.

Banik, P., A. Midya, B.K. Sarkar, and S.S. Ghose (2006). Wheat and chickpea intercropping systems in an additive series experiment: Advantages and weed smothering. Eur. J. Agron. 24: 325-332

Bilalis D, Papastylianou P, Konstantas A, Patsiali S, Karkanis A and Efthimiadou A. (2010). Weed-suppressive effects of maize-legume intercropping in organic farming. Int. J. Pest Manage., 56(2): 173-181.

Chang JF, Shibles RM (1985) An analysis of competition between intercropped cowpea and maize. The effect of fertilization and population density. Field Crop Res 12: 145-152.

Clark EA and Francis CA (1985). Transgressive yielding in bean: maize intercrops; interference in time and space. Field Crops Research 11: 37-53.

Connolly J, Goma HC, Rahim K (2001). The information content of indicators in intercropping research. Agric. Ecol. Environ. 87(2): 191-207. http://dx.doi.org/10.1016/S0167-8809(01)00278-X

CSA (2011). Agricultural Sample Survey 2010/2011. Reports on area under cultivation, yield and production of major crops for 2009/10-2010/11 main (Meher) season, Ethiopia.

CSA (2012). The Federal Democratic Republic of Ethiopia, Central Statistical Agency, Agricultural Sample Survey 2011/2012 (2004 E.C.) (September - December 2011). Volume I. Report on Area and Production of 
Major crops (Private Peasant Holdings, MEHER season). Statistical Bulletin, May, Addis Ababa, Ethiopia. Central Statistics Agency, Sample Survey (2007/2008): Statistical Bulletin 417

CSA (2004). Agricultural sample survey: Report on area under cultivation yield and production of the major crops. CSA, Addis Ababa, Ethiopia.

CSA. (2012). Central Statistic Authority. Agricultural Sample Survey: report on Area and production of major Crops (Private peasant holdings " $m e h e r$ " season), Volume I

Addis Abeba, Ethiopia.

Dajue, L. and H.H. Munde, (1996). Safflower Carthamus tinictorius L. Promoting the conservation and use of underutilized and neglected crops. Institute, of plant genetics and crop plant research, Gatersleben/International plant Genetic Resource Institute, Rome, Italy pp:83doi: 10.11648/j.aff.20140305.16.

Dhima KV, Lithourgidis AS, Vasilakoglou LB, Dordas CA, (2007). Competition indices of common vetch and cereal intercrops in two seeding ratio. Field Crops Res. 100: 249-256.

Engdawork Tadesse (2009). Understanding Teff: A Review of Supply and Marketing Issues.

Eskandari, H. and A. Ghanbari (2010). Environmental resource consumption in wheat and bean intercropping: Comparison of nutrient uptake and light interception. Notulae Scientia Biologicae 2: 100-103.

FAO (2002). Sesame production information. http://www.ecoport.org. Accessed on January 20

FAO (2010). Food and Agriculture organization of the United Nations. http://faostat.foa.org/ site/339/default.aspx

Flesch, Roger Delmar, "Wheat-soybean relay intercropping: Temporal and spatial effects " (1994). Retrospective Theses and Dissertations. Paper 11254.

Fukai S. Trenbath B.R. (1993). Processes determining intercrop productivity and yields of component crops. Field Crops Res. 34, 247-271.

G. Armach- Agyeman, J. Loiland, R. Karow and A.N. Hang (2002). Dry land cropping system (Safflower).

Gardner FP, Pearce RB, Mitchell RL (1984). Physiology of crop plants. Iowa State Press, p. 328.

Getachew A., Amare G., Woldeyesus S. 2006. Yield performance and land-use efficiency of barley and faba bean mixed cropping in Ethiopian high lands. Eurp J. Agron. 25: 202-207.

Ghanbari AA, Taheri-Mazandarani M (2003). Effects of sowing date and plant density on yield of spotted bean. Seed and Plant J. 19(4): 384-496.

Gholamreza R. D, Mehdi A., Shahverdi k., Morteza B., Raouf S., Sharifi, S., Hokmalipour and Shirin A.(2011). Evaluation of Yield and Yield Components In Potato-safflower Intercropping. Australian Journal of Basic and Applied Sciences, 5(11): 1423-1428

Gholamreza Zarei, Hossein Shamsi and Farjam Fazeli (2011). Effect of Planting Density on Yield and Yield Components of Safflower Cultivars in Spring Planting

Haftamu Gebretsadik, Mitiku Haile and Charles F. Yamoah, (2009). Tillage Frequency, Soil Compaction and NFertilizer Rate Effects on Yield of Tef (Eragrostis Tef (Zucc)Trotter) in Central Zone of Tigray, Northern Ethiopia Volume 1 (1): 82 - 94.

Hamelmal, (2015). Evaluation of Different Kinds and Time of Legume Intercropping with Teff in Habru Woreda, North Wollo Zone, Ethiopia (un published)

Hauggaard-Nielsen, H., P. Ambus, and E.S. Jensen (2001). Temporal and spatial distribution of roots and competition for nitrogen in pea-barley intercrops. A field studies employing $23 \mathrm{P}$ techniques. Plant and Soil 236: 63-74.

Helenius J, Jokinen K (1994). Yield advantage and competition in intercropped oats (Avena sativa L.) and faba bean (Vicia faba L.): Application of the hyperbolic yield density model. Field Crop Res 37:85-94.

Horn, P.W and O.C. Burnside, (1985). Soybean growth as influenced by planting date, cultivation and weed removal. Agron. J., 77: 793-795.

Ibrahim Yahuza (2012). Effects of different sowing date and the combined effects of sowing date and seed rates on the performance of wheat (Triticum aestivum L.)/faba bean (Vicia faba L.) intercropping system. International Journal of Agronomy and Agricultural Research (IJAAR) ISSN: 2223-7054 (Print), Vol. 2, No. 3, p. 24-40

J.L. Helm, N. Riveland, A.A. Schneiter, and J. Bergman (1991). Safflower Production. No. A-870, Cooperative Extension Service, North Dakota State University. Fargo

Khanzada, S., H.H. Khan, and M. Amin (2000). Economic productivity of safflower under different wheat intercropping pattern. Sarhad J.Agric. 16: 571-574.

Kidane G, Amare A, Adhonon N, Legesse D and Woldeyeuss. (1990). Cereal/Legume intercropping research in Ethiopia. In Waddington, R.S., A.F.E. Palmer, and O.T. Edje eds: Research methods for cereal/legume intercropping: Proceedings of a workshop on research methods for cereal/legume intercropping in Eastern and Southern Africa. Mexico, D.F: CIMMYT.

Li, L., S. Jianhao, Z. Fusuo, L. Xiaolin, R. Zdenko, and Y. Sicun (2001). Wheat/Maize or Wheat/Soybean strip 
intercropping, II. Recovery or compensation of maize and soybean after wheat harvesting. Field crop Res. 71: 173-181.

Li L., Yang S., Li X., Zhang F., Christie P. (1999). Interspecific complementary and competitive interactions between intercropped maize and faba bean Plant Soil 212:105- 114.

Lithourgidis, A. S., Vasilakoglou, I. B.,Dhima, K. V., Dordas, C. A., \& Yiakoulaki, M. D.(2006). Forage yield and quality of common vetch mixtures with oat and triticale in two seeding ratios. Field.Crops. Res., 99, 106- 113. http://dx.doi.org/10.1016/j.fcr.2006.03.008

Mandal B, Mahapatra S, (1990). Barley, lentil, and flax yield under different intercropping system. Agrono J. 82: $1066-1068$

Mazaheri D (1998). Intercropping. Tehran University Press, Tehran. p 262.

Mead, R. and R.W. Willey (1980). The concept of a "Land Equivalent Ratio" and advantages in yields from intercropping. Experimental Agriculture, 16:217-28.

Melak Agajie (2014). Effect of spacing on yield components and yield of chickpea (cicer arietinum 1.) At assosa, western ethiopia, un publish paper

MoARD (2008). Crop Variety Register, Ministry of Agriculture and Rural Development (MoARD), Animal and Plant Health Regulatory Directorate, Addis Ababa, Ethiopia, June 2008.

Moshatati A., Moussawi S.H., Fathi Gh. (2010). Effect of Sowing Date And Plant Density On Yield And Yield Components Of Cow Pea (Vigna Sinensis L.) In Ahwaz (Short Technical Report) Volume 3, Number 3; Page(S) 229 To 238

Motiei Langeroudi H, Shamsaei A (2009). Development and sustainable agriculture. Tehran University Press.

Moussawi S.H., Siadat S.A., Moshatatia., Enayat Gholizadeh M.R. (2010). Effects of inter and intra row spacing of sowing on yield and yield components of faba bean in ahwaz region, Volume 2, Number 4; Page(s) 1 To 7.

Nasri, R., A. Kashani, M. Barary, F. Paknejad, and S. Vazan (2014). Nitrogen uptake and utilization efficiency and the productivity of wheat in double cropping system under different rates of nitrogen. Int. J. Biosci. (IJB). 4(4): 184-193.

Oad, F.C., M.A. Samo, S.M. Qayylan and N.L. Oad. (2002). Inter and intra row spacing effect on the growth, seed yield and oil continent of safflower. Asian Plant Science Journal,1: 18-19.

Okubay Giday, Gibrekidan H, Berhe T (2014) Response of Tef (Eragrostis tef) to Different Rates of Slow Release and Conventional Urea Fertilizers in Vertisols of Southern Tigray, Ethiopia. Adv Plants Agric Res 1(5): 00030. DOI: 10.15406/apar.2014.01.00030

Ö. Öztürk, O. Şaman , (2012). Effects of Different Plant Densities on the Yield and Quality of Second Crop Sesame International Journal of Biological, Biomolecular, Agricultural, Food and Biotechnological Engineering Vol:6, No:9

Oseni T.O. (2010). Evaluation of sorghum-cowpea intercrop productivity in savanna agro-ecology using competition indexes, J.Agric. Sci. 2(3):229-234.

Osman A.N., Ræbild A., Christiansen J.L., Bayala J. (2011). Performance of cowpea (Vigna unguiculata) and Pearl Millet (Pennise tumglaucum) intercropped under Parkia biglobosa in an Agro forestry System in Burkina Faso. African Journal of Agricultural Research 6(4):882-891.

Putnam DH and Allan DL (1992). Mechanisms for over yielding in a sunflower/mustard intercrop. Agronomy Journal 84: 188-190.

Salehi M., Akbari R., Khorshidi M.B. (2006). Review of performance and components of grain yield response to delayed planting beans in the middle region, Journal of Agriculture and Natural Resource Sciences $43105-$ 114.

Samsuzzaman S, Karim MMA, Ali MA, Mohiuddin M, (1995). Performance mustard (Brassicajuncea) and chickpea (Cicerarietinum) intercropping at varying levels of population in the farmers. field J. Bio Sci. 3: $171-176$

Seran T.H., Brintha I. (2010). Review on maize based intercropping. Journal of Agronomy 9 (3): $135-145$.

Seyfu Ketema. (1993). Tef [Eragrostis tef (Zucc.) Trotter]. Breeding, Genetic Resources, Agronomy, Utilization and Role in Ethiopian Agriculture. Institute of Agricultural Research, Addis Ababa, Ethiopia.

Seyfu Ketema 1997. Tef [Eragrostis tef (Zucc) Trotter] Promoting the conservation and use of underutilized and neglected crops Institute of plant genetics and crop plant research Getersleben International plant genetic resources, Rome, Italy.

Seyfu Ketema. (1989). Production trends, germplasm resources, breeding, and varietal improvement of small millets, with special emphasis on tef in Ethiopia. In: Seetharam A, Riley KW and Harinarayana G (eds). Small millets in Global Agriculture. IDRC, Oxford and IBH Co., India.

Syaifuddin. (2008). A Review on Potential Land to Grow Corn in Gowa and Takalar Regencies. Dissertation of Postgraduate Program University of Hasanuddin, Makasar.

Tadesse, M. (2004). Asteraceae (Compositea). In: Hedeberg I, Ib Friis and S. Edwards (eds.), Flora of Ethiopia 
and Eritrea, Vol. 4 Part 2. The National Herbarium, Addis Ababa University, Addis Ababa and Uppsala.

Tahereh Emami, Rahim Nasen, Hadi Falahi and Eftekhar Kazemi (2011). Response of Yield, Yield Component and Oil Content of Safflower (cv. Sina) to Planting Date and Plant Spacing on Row in Rainfed Conditions of Western Iran. American-Eurasian J. Agric. \& Environ. Sci., 10(6). 947-953.

Tamiru Hirpa (2013). Maize productivity as affected by intercropping date of companion legume crops. Peak J. Agric. Sci. 1(5):70-82.

Tamiru Hirpa (2014). Response of maize crop to spatial arrangement and staggered interseeding of haricot bean. Journal of Agricultural and Crop Research Vol.2(7), pp.143-151

Tareke Berhe and Nigusse Zena (2008). Results in a trial of system of Tef intensification (STI) at Debre zeit, Ethiopia.

Tefera, H., Ayele, M., Assefa, K., (1995), 'Improved varieties of tef (Eragrostis tef) in Ethiopia. Releases of (1970-1995), Research Bulletin No. 1, Debre Zeit Agricultural Research Centre, Alemya Iniversity of Agriculture, Debre Zeit, Ethiopia.

Tefera, H., Assefa, K., Hundera, F., Kefyalew, T., Teklu, Y., Gugsa, L., Ketema, S., Adnew, T., (2001). 'Progress of tef breeding research in Ethiopia', in: H. Tefera, G. Belay, M. Sorrells (eds), Narrowing the Rift. Tef Research and Development Proceedings of the International Workshop on Tef Genetics and Improvement, Debre Zeit, Ethiopia, 16-19 October 2000, 157-163.

Tesfu Mengistu and Charles Yamoah (2010). Effect of sowing date and planting density on seed production of carrot (Daucus carota var. sativa) in Ethiopia. African Journal of Plant Science Vol. 4(8), pp. 270-279

Tsubo, M., S. Walker, and E. Mukhala (2001). Comparisons of radiation use efficiency of mono-/inter-cropping systems with different row orientations. Field Crops Res. 71: 17-29.

Vasilakoglou I, Dhima K, Lithourgidis A, Eleftherohorinos I, 2008. Competitive ability of winter cerealcommon vetch intercrops against sterile oat. Experimental Agriculture 44: 509-520.

Wahla I. H., R. Ahmad, Ehsanullah, A. Ahmad, A. Jabbar (2009). Competitive functions of components crops in some barley based intercropping systems. Int. J. Agric. Biol., 11: 69-72.

Walelign Worku (2004), Maize-tef relay intercropping as affected by Maize planting patern and leaf removal in southern Ethiopia. Published in African Crop Science journal, Vol.12, No, 4, pp.358-36

Wajid A., A. Ghaffar M. Maqsood K. Hussain, W. Nasim (2007). Yield response of maize hybrids to varying nitrogen rates. Pak. J. Agric. Sci. 44(2): 217-220.

Whigham, D.K. (1985). Strip and relay intercropping of soybeans, p. 1025-1031. In R.M. Shibles (ed.). World Soybean Research Conference III: Proceedings. West view Press, Inc., Boulder, Colorado.

Willey RW (1990). Resource use in intercropping systems. Agric Water Manage 17: 215-231

Willey, R.W. (1979). Intercropping. Its Importance and Research Needs. Competition and Yield Advantages. Field Crop Abstract, 32(1):2.

Willey, R.W. (1985). Evaluation and presentation of intercropping advantages. Experimental Agriculture, 21:119-133.

Wondimu Bayu, Molla Addisu, Besufekad Tadesse and Legesse Admassu (2007). Intercropping tef and sunfl ower in semi-arid areas of Welo, Ethiopia. Published online in Wiley InterScience.

Yayeh Bitew, Fekremariam Asargew, Oumer Beshir (2014). Effect of Plant Spacing on the Yield and Yield Component of Field Pea (Pisum Sativum L.) at Adet, North Western Ethiopia. Agriculture, Forestry and Fisheries. Vol. 3, No. 5, pp. 368-373.

Yayeh Bitew, Fekremariam Asargew (2014). Rice (Oryza Sativa) and Chickpea (Cicer aritinum L) Relay Intercropping Systems in an Additive Series Experiment in Rain Fed Lowland Ecosystem of Fogera Vertisols. Science Research. Vol. 2, No. 6, pp. 179-184.doi: 10.11648

Yildirim, E. and I. Guvence (2005). Intercropping based on cauliflower: more productivity, profitable and highly sustainable. Eur. J. Agron. 22: 11-18. 